\title{
Women's Participation in the Local Government as Voters, Candidates and Mayors in the North East Region of Romania
}

\author{
Andreea-Daniela Fedor, Corneliu Iațu \\ Faculty of Geography and Geology, Alexandru Ioan Cuza University of Iași, Iași, Romania \\ Email: andreea.fedor@yahoo.com,corneliu.iatu@gmail.com
}

How to cite this paper: Fedor, A.-D., \& Iațu, C. (2021). Women's Participation in the Local Government as Voters, Candidates and Mayors in the North East Region of Romania. Open Journal of Political Science, 11, 108-123.

https://doi.org/10.4236/ojps.2022.121007

Received: December 1, 2021

Accepted: January 26, 2022

Published: January 29, 2022

Copyright $\odot 2021$ by author(s) and Scientific Research Publishing Inc. This work is licensed under the Creative Commons Attribution International License (CC BY 4.0).

http://creativecommons.org/licenses/by/4.0/

\begin{abstract}
Most of the studies focus on the high representation of women in politics such as in Parliament, Government or Euro Parliament, while little attention is given to the local government despite its importance within the national politic system. Therefore, the aim of this research is to better analyze, observe and understand the dynamics of women's participation at the electoral process in the local government as candidates and winners, but also as voters in the North East Region of Development of Romania. The focus is on the progress made or not toward gender equality in political decision making in the 32 years of democracy. More precisely, how substantial are the changes, after 7 elections, regarding the number of women that chose to run for elections, to what extent were they voted and how high is the success rate of success when compared to the male-candidates. The methodology consists in descriptive analysis of the political representativity, depending on the identified evolution trends, correlated with the Regions of Romania and political parties. To carry out this study, quantitative and qualitative methods were combined. The analyzed data for the local election from 1996 to 2020 focus on the studied area-North East Region which has the highest level of female mayors when compared with the others. The results show an under-representation of women in local government with a percentage of $6.34 \%$ female mayors, 1 percentage higher than at national level (5.33\%). Moreover, $84.20 \%$ of administrative units have never had a female mayor. Also, the women's rates of success are lower $(15.28 \%$ in 2020$)$ when compared to their male counterparts $(22.26 \%)$ (ROAEP).
\end{abstract}

\section{Keywords}

Local Government, Female Voters, Female Candidates, Female Mayors, North-East Region 


\section{Introduction}

Despite the fact that women represent $50 \%$ of the Romanian population (INS), at local level there are around only $5.33 \%$ female mayors (ROAEP), a percentage that places our country at the bottom in the EU and Central and Eastern European Countries (CEECs) ranking. In the present research, the references will be done to the CEECs as Romania shares the common communist past, the challenging transition and the organizational heritage in terms of gender equality. The lack of female-leaders in politics and decision-making positions is presented as a women's choice, yet there are evidences that it is a consequence of cumulative factors of social, political and cultural nature (Matei et al., 2010; Băluță, 2012; Gârboni, 2014). It must be underlined the fact that female interests may be better served if women are given decision making capabilities to raise their voice in the decision making bodies (Swai \& Anasel, 2020). Also, a balanced political participation leads to a higher citizen representation of needs and surpasses the stereotypical mentality that politics are a masculine job (Galligan \& Clavero, 2005).

First of all, the transition from a non-democratic political regime to a democratic one was marked by a severe economic, social and political crisis (Gârboni, 2014) that caused an unprecedented instability in Romania (Massino \& Popa, 2015) followed by a wave of emigration to Europe that diminished the population (Dumitriu et al., 2013; INS). Given this context, the women's involvement within politics did not represent a priority even if the democratic road on which the Central and Eastern European countries stepped on was supposed to take them to freedom, civil liberty and prosperity which implied a higher number of women in decision making, too.

Thus, as the data (Table 1) shows that there are former communist countries which have $21.45 \%$ (Hungary) and $25.27 \%$ (Slovakia) female mayors which exceed the EU average and place them among Finland and Netherlands. And, at the same time, former communist countries such as Romania and Albania have the lowest percentage of female-mayors. Overall, most of the countries have a percentage of $10 \%-13 \%$ female mayors which places the countries away from the criticized "critical mass" of 35\% (Childs \& Krook, 2006; Childs \& Krook, 2008; McGregor \& Webster, 2007).

The analyzed data indicate that in 2011 Romania, Slovenia and Croatia have very similar percentages of female mayors, while if the same countries' data from 2021 are compared, it can be observed that Slovenia and Croatia doubled while Romania had a slight improvement. Latvia instead shows a high decrease from $23.53 \%$ to 6.98 following the reorganization of local governments in 2020 from 118 municipalities to 41 municipalities -6 cities and 35 counties (Kāršenieks, 2016). For most of all CEEC former communist countries, the trend is upward and (for Albania there are data only for three years, so little can be observed) and quite fast except for Romania. Of course, this is a consequence of the way in which the states, parties and the population supported women's involvement in local, national and international politics.

Secondly, the reforms adopted regarding (1) legislated gender quotas and (2) 
the electoral legislation for the local elections made the former communist countries from Central and Eastern Europe to experience differently the transition with slower or faster progress towards gender equality in politics.

In what concerns (1) the legislated quotas (Table 2), four out of ten countries chose to have legislated candidate quotas: Slovenia $(35 \%, 2006)$, Poland $(35 \%$,

Table 1. The percentage of female mayors or other leader of the municipal council (or equivalent) in ECE countries. Source: European Institute of Gender Equality http://eige.europa.eu.

\begin{tabular}{ccccccccc}
\hline Countries/Years & 2011 & 2013 & 2015 & 2017 & 2019 & 2020 & 2021 \\
\hline Albania & & & & 13.11 & 13.11 & 13.11 \\
Bulgaria & 10.61 & 10.98 & 10.98 & 12.83 & 13.21 & 13.96 & 13.96 & 10.99 \\
Croatia & 4.86 & 7.04 & 7.04 & 7.04 & 9.01 & 9.01 & 14.81 & 14.81 \\
Czechia & 8.70 & 8.70 & 4.17 & 4.17 & 4.17 & 17.99 & 18.99 \\
Estonia & 10.62 & 10.62 & 12.80 & 12.80 & 16.46 & 18.99 & 21.40 & 21.45 \\
Hungary & 10.66 & 10.66 & 20.14 & 20.48 & 20.38 & 23.53 & 23.53 & 6.98 \\
Latvia & 20.17 & 24.37 & 24.37 & 24.37 & 23.53 & 8.33 & 8.33 \\
Lithuania & 6.67 & 10.00 & 5.26 & 8.33 & 8.33 & 12.04 & 12.04 & 12.04 \\
Poland & 8.96 & 8.96 & 10.75 & 10.73 & 4.52 & 4.52 & 4.52 \\
Romania & 3.48 & 4.27 & 4.27 & 4.52 & 25.27 & 25.27 \\
Slovakia & 22.41 & 22.41 & 23.26 & 23.26 & 25.25 & 25.27 & 10.38 & 10.38 \\
Slovenia & 4.81 & 4.81 & 7.55 & 7.55 & 10.38 & &
\end{tabular}

Table 2. Legislated quotas in ECE countries. Source: International Institute of Democracy and Electoral Assistance, https://www.idea.int/.

\begin{tabular}{|c|c|c|c|c|c|}
\hline Country & $\begin{array}{c}\text { Parliament } \\
\text { type }\end{array}$ & $\begin{array}{l}\text { Voluntary political } \\
\text { party quotas }\end{array}$ & $\begin{array}{c}\text { Single/Lower House > } \\
\text { Quota type }\end{array}$ & $\begin{array}{c}\text { Single/Lower House }> \\
\text { Constitutional quota } \\
\text { details }\end{array}$ & $\begin{array}{c}\text { Single/Lower House }> \\
\text { Electoral law quota } \\
\text { details }\end{array}$ \\
\hline Albania & Unicameral & No & Legislated Candidate Quotas & No & Yes \\
\hline Bulgaria & Unicameral & No & No Legislated & No & No \\
\hline Croatia & Unicameral & Yes & Legislated Candidate Quotas & Yes & Yes \\
\hline Czechia & Unicameral & No & No Legislated & No & No \\
\hline Estonia & Unicameral & No & No Legislated & No & No \\
\hline Hungary & Unicameral & Yes & No Legislated & No & No \\
\hline Latvia & Unicameral & No & No Legislated & No & No \\
\hline Lithuania & Unicameral & Yes & No Legislated & No & No \\
\hline Poland & Bicameral & No & Legislated Candidate Quotas & No & Yes \\
\hline Romania & Bicameral & Yes & No Legislated & No & No \\
\hline Slovakia & Unicameral & Yes & No Legislated & No & No \\
\hline Slovenia & Bicameral & Yes & Legislated Candidate Quotas & No & Yes \\
\hline
\end{tabular}


2011), Albania $(30 \%, 2015)$ and Croatia $(30 \%, 2015)$ while Romania, Slovakia Lithuania, Hungary have no legislated, but voluntary party quotas (slated, but voluntary party quotas (European Institute of Gender Equality). This may be a first step as in Slovenia's case that succeeded to introduce legal quotas in 2005 that bought significant changes in the representation of women (Selisnik \& Gaber, 2015). At the same time, in Poland researchers claim that the quotas helped to increase women's' representation (Köppl-Turyna \& Kantorowicz, 2020) but alone are not sufficient to ensure high levels of women's representation (Millard, 2014) in the absence of other legal measures such as zipper system for instance.

Meanwhile, in Bulgaria and Czech Republic there are no legislated or voluntary party quotas. Obviously, the quotas are applied for the national assembly as in the local election only one candidate can be nominated. Yet, the national quotas can, in time, influence the local elections too, especially in the societies that have prejudices regarding women in politics. At the same time, it can indicate women's involvement in acquiring these rights and/or the state's interest in what concerns gender equality in politics.

Also, an important aspect to be taken into account is (2) the way in which mayors are elected as local administration; in Europe it follows two models: direct elections by citizens or chosen from among the council members (CEMR, 2010).

In Albania (1990), Croatia (2009), Hungary (1994), Poland (2002), Romania (1990), Slovakia (1990), Slovenia (1990), and Bulgaria (1990), mayors are directly elected by citizens (Podolnjak \& Gardašević, 2013; Várnagy \& Ilonski, 2012; Rajca, 2021, Czyż, 2009; Gorecki \& Gendźwiłł, 2020) while in the other countries the situation is different. For instance, in Estonia the mayor is appointed by the municipal council, in Lithuania and Czechia is elected by and from within the local council for four year and in Latvia the chairman of the local council is elected by and from within the local council (CEMR, 2011).

The direct elections of mayors in local government can become conflictual and unproductive when the mayor and local council majority represent different political options (Podolnjak \& Gardašević, 2013). Yet, direct election of mayors by the citizens is a procedure increasingly used in Council of Europe member states to appoint the head of the executive (CLRAE, 2004).

\section{Methodology}

Romania is organized in eight regions of development that have a total of 3181 administrative units divided in 103 municipalities, 217 cities and 2861 communes, each of them composed of more villages which do not have administration of their own (Ordonanța de urgență 57/2019).

In this paper the research area and the analysis scale were defined and delimited to the North-East Region which has the largest population of all the regions $3,171,331$ inhabitants (16.64\% of the Romanian population) out of whom $2,460,068$ above 18 years old, which means that $76.91 \%$ have the right to vote. It is composed of 17 municipalities, 29 cities, 506 communes. Female 
represent $50.29 \%$ of the population in the studied area, less than at national level $51.18 \%$, with a lower presence in the $30-54$ cohorts and a higher presence in the +60 cohorts (INSSE 2016). There is a particularity in the Romanian-s population due to the 1967 Decree so that $22.11 \%$ of the population is represented by the 40 - 54 cohorts.

Within the study the quantitative (statistical analysis and qualitative methods, online data collection) and qualitative (literature review) are combined in order to better understand women's involvement in politics and how it evolved.

Thus, a 32-year database, from 1996 to 2020, on the number of candidates running for local election and winners of the elections was extracted from the Permanent Electoral Authority which can be accessed publicly on the website of the agency. The focus was on candidates, their parties and gender, winners and their parties and gender, and turnout. It must be underlined that in 2000 there are no officially validated statistics on the number of candidates, their gender nor the party to which they belong. Therefore, we take into account the fact that our analysis may be influenced by this lack of data. Also, for 1996, 2008 and 2020 the official databases were not classified by gender, which means that they were processed manually and the authors drew attention to the fact that there may be a margin of error of $3 \%-5 \%$.

Also, the 2020 databases of voter turnout, migration and population were extracted from the national official sites (Permanent Electoral Authority, National Institute of Statistics).

The qualitative method consisted in the qualitative speech on women in leading positions and political life in the Central and Eastern European from comparative perspective.

\section{Female Voters}

In this section analysis will concentrate on women's participation in politics in North-East Region of Romania to understand whether there are differences in political participation.

The universal right to vote in Romania was adopted in 1948 as part of the communist propaganda regarding equality; before that women did not have the right to vote, except for +30 educated women had this right in the 1938's constitution.

During the communist period both male and female were very active citizens and the percentages of voter turnout were almost full. After 1989 the enthusiasm about voting gradually decreased (Kostadinova, 2003) and the percentages in voter turnout have dropped on all the elections, despite the transformations of strategies election campaign, based especially on the technological development (Răuţu, 2020). In what concerns the local elections it had a sinuous trend from $65 \%$ in 1992 to $56.47 \%$ in $1996,50.85 \%$ in $2000,54.23 \%$ in $2004,48.81 \%$ in $2008,56.39 \%$ in 2012, 48.44\% in 2016 and the lowest presence of $45.57 \%$ in 2020 (Table 3).

Yet, the voter turnout in the local elections is similar to the other CEE countries 
Table 3. Vote turnout in local elections. Data source: http://alegeri.roaep.ro.

\begin{tabular}{ccccccccc}
\hline Year & 1992 & 1996 & 2000 & 2004 & 2008 & 2012 & 2016 & 2020 \\
\hline Percentage & $65 \%$ & $56.47 \%$ & $50.85 \%$ & $54.23 \%$ & $48.81 \%$ & $56.39 \%$ & $48.57 \%$ & $45.57 \%$ \\
\hline
\end{tabular}

like Bulgaria 51.8\% in 2011, Latvia 46\% in 2013, Czech Republic $44.4 \%$ in 2014, Hungary 44.3\% in 2014, Poland 47.4\% in 2014 (Gorecki \& Gendźwiłł, 2020; Ladner et al., 2019).

These lower levels of participation among Eastern European citizens are often explained through the historical experience with communism (Coffé \& Kostadinova, 2003). The higher voter turnout in 2012 could be explained through the political system change that took place in Romania from the two-round system to one round system.

In the studied area both male and female have low levels of participation in voting and there is little difference between the young cohorts, while in the +65 cohorts there can be observed differences of two percentages showing a higher interest of women in politics, yet it is due to the higher life expectancy. At the same time, the 45 - 64 men in Iasi, Botoșani and Vaslui show a higher interest in voting than women, which can be explained through the higher number of men in these cohorts. Thus it can be confirmed the Coffe's findings that conclude that middle cohorts are much more involved in politics than the young and elderly cohorts.

In the studied area there is a low voter turnout, especially in Iași (37.21\% in 2020 ) and Vaslui (37.14\% in 2020) counties, which have the lowest levels of participation in voting at national level. It can be explained through the massive migration from the region (Comșa, 2015) and through the high number of Moldavian citizens that obtain via the practice of citizenship re-acquisition (redobândire) the Romanian citizenship that permitted large numbers of Moldovan residents to reacquire Romanian citizenship, while retaining Moldovan citizenship (since 2003) and residing in Moldova (Knott, 2017). Although they may be interested in participating within the Romanian political life through the diaspora voting, as demonstrated in the presidential election (Knott, 2017), the local government election is not facilitated to the diaspora. Between 1990 and 2010, the migratory balance in Romania reached an impressive number in the official data which related to the total population is $5 \%$, but part of the migration was illegal, thus unregistered (Dumitriu et al., 2013). The studied region has always had the highest percentage of migration at national level. Also, between 2012 and 2020 in the studied area the number of emigrants increased constantly representing in the given period around $16 \%$ of the total (INSSE). The dynamics changed in what concerns the gender as in 2012 and 2013 women migrated more than men while after 2014 the number of women decreased in comparison with men.

Besides, the high distrust in the social and political institution, legacy of Communist rule (Mishler \& Rose, 1997) that affects the voter turnout, too. In 1997, when Mishler study was conducted, Romania and Bulgaria registered the highest distrust among the CEECs explained through the repression of human 
rights and freedoms that they experienced.

The voter turnout in 2020 at local elections in North-East Region. Source: https://prezenta.roaep.ro/.

\begin{tabular}{ccccccc}
\hline Cohorts percentage/county & Bacau & Botosani & Iasi & Neamt & Suceava & Vaslui \\
\hline $18-24$ male & 4.05 & 4.46 & 4.50 & 4.12 & 4.48 & 4.48 \\
$18-24$ female & 4.04 & 4.45 & 4.48 & 3.89 & 4.60 & 4.24 \\
$25-34$ male & 5.91 & 5.69 & 7.35 & 5.85 & 6.64 & 5.62 \\
$25-34$ female & 6.18 & 6.09 & 7.41 & 5.99 & 7.00 & 5.65 \\
$35-44$ male & 8.70 & 8.51 & 9.99 & 8.41 & 8.89 & 8.37 \\
$35-44$ female & 8.83 & 8.81 & 9.69 & 8.61 & 9.07 & 8.46 \\
$45-64$ male & 19.94 & 19.36 & 18.77 & 19.83 & 19.20 & 20.76 \\
$45-64$ female & 19.70 & 18.06 & 17.42 & 19.20 & 18.91 & 18.60 \\
$65+$ male & 10.21 & 10.87 & 9.28 & 10.99 & 9.99 & 10.76 \\
$65+$ female & 12.43 & 13.70 & 11.11 & 13.12 & 11.22 & 13.06 \\
\hline
\end{tabular}

*The data are calculated from the total number of votes cast and are not related to the voting population of the related cohorts.

\section{Female Candidates}

According to the legislation the Romanian citizens who have reached the age of at least 23 years by Election Day inclusive have the right to candidate for mayors (Legea nr. 115/2015). The candidates that choose to run for the local elections can be independent or part of a party; yet, most of them are party members and, in this case the candidacies for mayors are proposed by the political parties or political alliances established according to the Law on political parties no. 14/2003, republished. Out of the four most important parties at the moment which are the only ones with parliamentary representation PNL, PSD, USRPLUS, UDMR, only one has a specific and clear methodology regarding the candidacies' proposal to mayoral elections in their party status (Statutul Partidului PSD; Statutul Partidului PNL; Statutul Partidului UDMR; Statutul Partidului USRPLUS). Thus, political parties play a decisive role in candidate's recruitment being gatekeepers and power players for fair representation of women (Kantola, 2019) with the opportunity to balance their tickets with women (Montgomery \& Ilonski, 2016).

In what concerns the communes', cities' or municipalities' geographicaldemographics sizes, there is no difference regarding the electoral process for mayors as in Bulgaria.

In Romania, as in the CEE countries, there are no quotas regarding female candidates for mayoral elections, but given the parties' role, with a good strategy the number of women in local government could be increased. At the same time, at the moment in Romania parties are male dominant and it can affect the women's recruitment by shadowy arrangements made in candidate selections 
(Sundstrom \& Wängnerud, 2016).

Regarding the women's involvement in politics as candidates, in the studied area between 1996 and 2020 it can be observed an ascending trend with the exception of 2012 when the number decreased. Thus, in the given period, at the 7 local elections, $16 \%$ of the administrative units have never had a female candidate while only $6.5 \%$ of the administrative units had at least 7 candidates for the same period. The low percentage of candidacies from 2012 can be a consequence of the amendment of the electoral law when the two-round system for mayors was modified in one round. The legislative amendment influenced the total number of candidates as it reduced considerably (Table 4). If before the amendment, the average of candidates 6.36 candidates per UAT in 2008, 4.65 candidates per UAT in 2020 with the mention that there is a higher competition in urban areas than in rural. For instance, in 2020 the average number of candidates in urban area was 7 , but the highest number of candidates was at municipality's level where 402 candidates run for the 41 county seats. Of these, 15.17 were female candidates with the average age of 47 years old.

As in Latvia's case when the administrative reorganization led to a lower number of female mayors, in North East Region in 2012 the number of female mayors decreased. Thus, it can be observed the vulnerability of female candidates facing the legislative amendments and changes and little capacity to adapt.

An important aspect that could be observed is that there is no correlation between the number of candidates and the voter turnout. Thus, even considered before that a higher number of candidates may imply a higher voter turnout, the data show that the there is no connection.

Table 4. Total candidates and female candidates by county in 1996-2020. Data source: roep.

\begin{tabular}{clccccccc}
\hline County & & 1996 & 2000 & 2004 & 2008 & 2012 & 2016 & 2020 \\
\hline \multirow{2}{*}{ Bacău } & Total candidates (nr) & 580 & N/A & 633 & 631 & 475 & 492 & 457 \\
& Female candidates & 44 & N/A & 54 & 54 & 37 & 61 & 60 \\
\multirow{2}{*}{ Botoșani } & Total candidates (nr) & 447 & N/A & 566 & 542 & 385 & 391 & 375 \\
& Female candidates & 30 & N/A & 45 & 43 & 33 & 38 & 40 \\
\multirow{2}{*}{ Iași } & Total candidates (nr) & 521 & N/A & 712 & 612 & 506 & 464 & 484 \\
& Female candidates & 31 & N/A & 65 & 52 & 36 & 41 & 41 \\
\multirow{2}{*}{ Neamțț } & Total candidates (nr) & 420 & N/A & 588 & 494 & 358 & 446 & 379 \\
& Female candidates & 23 & N/A & 43 & 38 & 27 & 53 & 34 \\
\multirow{2}{*}{ Suceava } & Total candidates (nr) & 591 & N/A & 763 & 674 & 537 & 478 & 466 \\
& Female candidates & 23 & N/A & 51 & 32 & 29 & 38 & 31 \\
\multirow{2}{*}{ Vaslui } & Total candidates (nr) & 397 & N/A & 693 & 553 & 369 & 417 & 394 \\
& Female candidates & 20 & N/A & 52 & 29 & 27 & 43 & 39 \\
\hline
\end{tabular}


A higher number of candidates do not influence the voter turnout, but rather the size of the administrative unit, being demonstrated that turnout is higher in small municipalities than in large (Frandsen, 2002). Dahl and Tufte claimed that citizens' motivation to participate in community affairs Dahl and Tufte hypothesis, in that turnout is consistently higher over time in small municipalities.

\section{Female Mayors}

According to the legislation, for each administrative unit there is elected through universal, direct, secret and free vote a mayor and a council whose number of members is distinct in each case. This is established by the prefect, depending on the number of inhabitants of the commune, city or municipality, reported by the National Institute of Statistics on 1 January of the current year or, as the case may be, on 1 July of the year preceding the elections (Legea nr. 215/2001).

The mayor and the local councilors serve four-year terms, period in which they can interrupt their governance due to personal reasons or be removed for legal reasons. Starting $2012 \mathrm{he} / \mathrm{she}$ is elected in one round due to electoral system change adopted for economic reasons, before that, mayors were elected in two rounds.

The mayor in Romania is elected directly by citizens and he/she is the local authority's executive body with the mention that the government did not limit the number of terms of office, one having the possibility to be mayor for lifetime.

The first democratic elections at local level (mayors) in Romania were in 1992 and till 2021 there were eight elections in which the percentage of female mayors grew from $2.44 \%$ in 1996 (translated in 71 female mayors) to $5.33 \%$ in 2020 (165 female mayors) with little differences between the eight NUTS 2 regions. In the North East Region, the number of female mayors increased from $3.43 \%$ to $6.70 \%$, far behind the at least 30\% “critical mass". Out of the 552 administrative units: 17 municipalities, 30 cities and 505 communes, with only one exception, female mayors won their candidacy in rural communities where there is less power, which attract fewer men, and leave more open spaces for women (Sloat, 2004; Timar, 2004) while in the big cities they have left little room for manoeuvre (Timar, 2004, 2005). Yet, the geographical-demographic size of a administrative unit does not affect the mayors' job as in Hungary's case where a mayor may be employed on a part-time basis in municipalities with less than 3500 inhabitants (Várnagy \& Ilonski, 2012; Timár, 2005).

In the studied area only $25.8 \%$ of the administrative unit had at least a female mayor in the period 1996-2020 while $84.2 \%$ have never had a female. In most of the cases, the administrative units in which female mayors obtained more than four mandates have the same candidate. Thus the typology of communes according to the number of mandates of women mayors would be:

1) administrative units in which the female mayors obtained 6 mandates in the period 1996-2020: George Enescu (BT), Vânători-Neamț (NT), Soleşti and Vutcani (VS);

2) administrative units in which the female mayors obtained 5 mandates in the 
period 1996-2020: Tamaşi (BC), Mironeasa (IS), Boteşti, Gârcina and Săbăoani (NT);

3) 12 administrative units in which the women mayors obtained 3 - 4 mandates between 1996 and 2020;

4) administrative units in which women mayors obtained $1-2$ mandates in the period 1996-2020: 63 communes, 11.39\%;

5) administrative units in which women mayors obtained zero mandates in the period 1996-2020: $466,84.2 \%$.

During the three decades there can be identified numerous legislative changes that have affected both the political parties system and on the voting behavior (Gârboni, 2014), yet they did not necessarily took into account a strategy to encourage women's involvement and gender equality in politics. Thus, transition did not favor women's advancement in politics as representatives, and they gained more terrain in the private sector (Gârboni, 2014). Thus, consistent changes of the electoral system should be adjusted regarding the gender equality in politics.

\section{Results and Conclusions}

The results of the present paper show that in the Romanian North East Region of Development in Romania women participate within the local government mostly as voters at a higher extend than as candidates and mayors. Despite the low voter turnout due to the communist past and socio-economic reasons as migration and immigration, there were no registered significant differences between the male and female participating in voting, except for the +65 female cohorts and 46 - 54 male cohorts (INSSE, ROAEP). This situation continues in the 37 administrative units where female won the candidacies, which shows that the gender of the candidate does not yet influence the voters' mobilization. Yet, in the

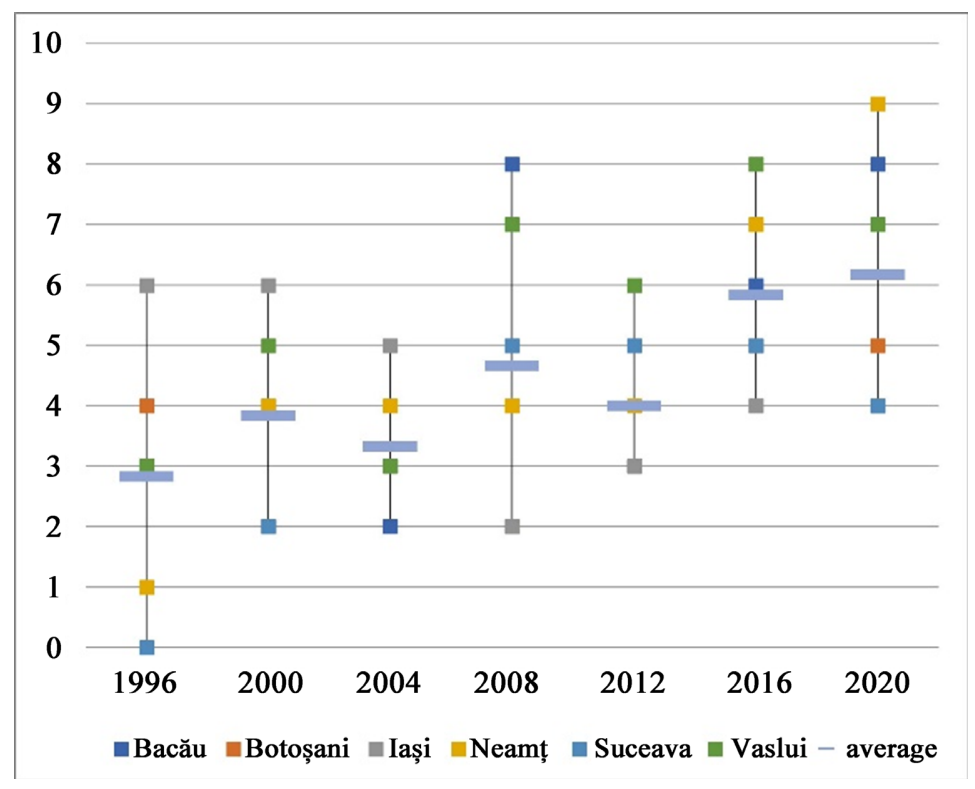

Figure 1. Number of elected women (mayors) in NE region, 1996-2020. 
administrative units where female won the candidacies, the voter turnout had an average of $51.74 \%$ in comparison with the NE Region average of $41.53 \%$ (AEP), showing a greater mobilization of the electorate.

Regarding women's candidacies, the study shows there are two counties Botoșani and Bacău that have exceeded the 10\% treshhold of candidates in 2016 and 2020 and they stand out through a higher participation of women as candidates in contrast with Suceava County (Figure 2). It was also observed that female run for election at a higher extend as independent candidates than supported by a

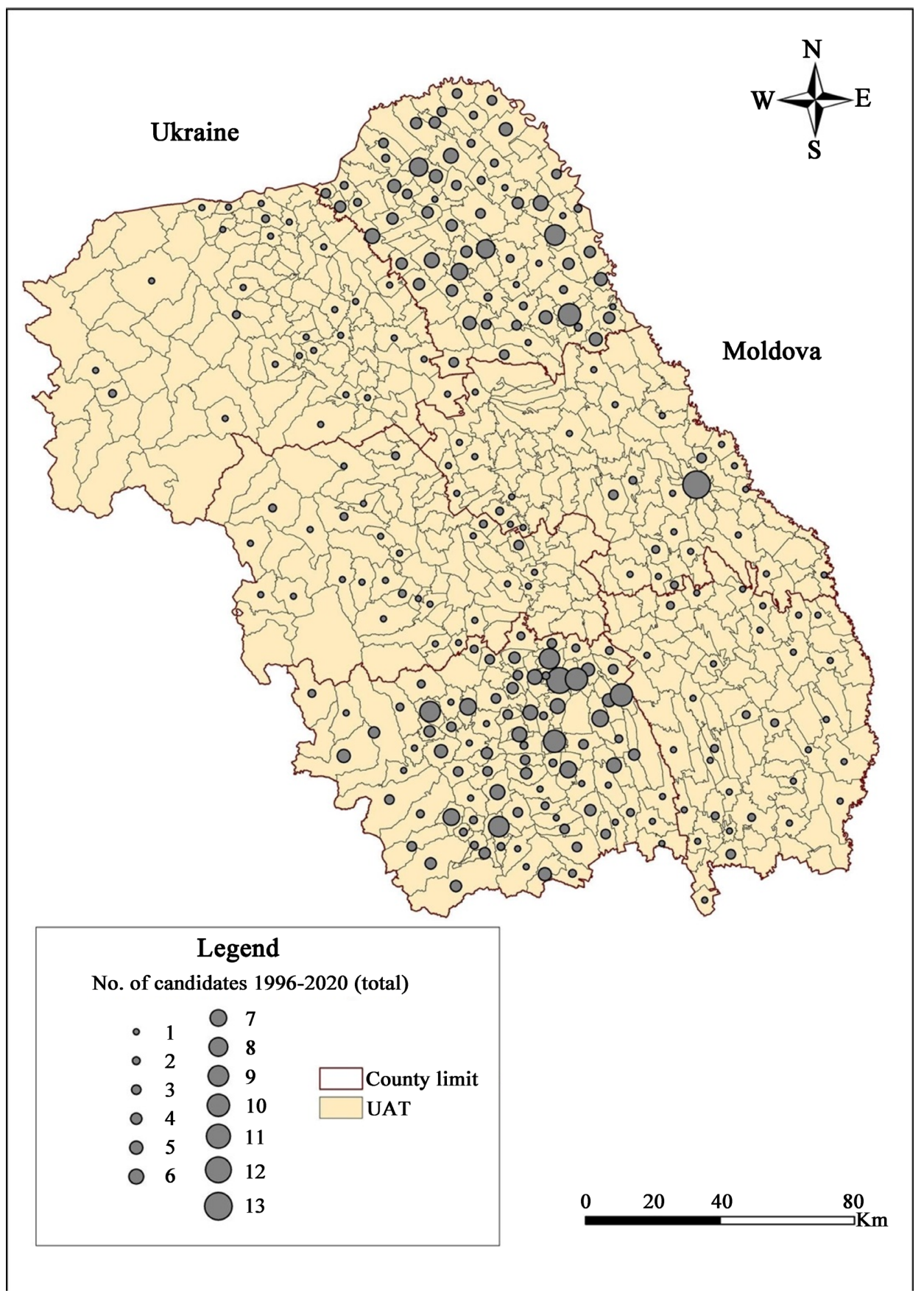

Figure 2. Total number of candidates by administrative unit between 1996 and 2020, source: BEC. 
party. Until 2016 in Romania, the 10\% threshold of female candidates was exceeded only by the independent candidates, which shows a reluctance and low interest of the parties to nominate women as candidates (Fedor et al., 2021).

In what concerns female as mayors, in the North East Region women are under-represented in the local government with only $6.34 \%$ female mayors at the last elections in 2020 (35 out of 552 administrative units). In the 1996-2020 period, there was registered a slight increase (from 3.43 in 1996 to 6.34 in 2020), which means that a national strategy with a proper legislation is required as in the case of Croatia, Poland or Slovenia. At the same time, the most important four parties PNL, PSD, UDMR, USR should formulate policies, regulations and set governance priorities to promote parity in their internal structures to encourage women to be more active.

A solution to a higher voter turnout could be the Estonian example of e-voting or the legislation of diaspora voting for local elections. The e-voting mobilizes more casual voters and young citizens as it is more attractive for younger voters and less so for elderly people (Alvarez et al., 2009). Yet, when it comes to the progress made regarding females as candidates and mayors, a gender gap is evident from national data and statistics, indicating a low interest of government and political parties in promoting gender equality. The biggest challenge in increasing women's political participation may not be legal but cultural and attitudinal, as the persistence of rigid gender roles and stereotypes hinders both men's and women's career choices and self-realization (Sloat, 2004).

Even if it is considered that individual politicians by themselves have little power to influence political outcomes (Sung, 2011), when it comes to smaller communities, the chances are higher for a political candidate who run for mayor office to know their community and win the competition (Fedor et al., 2019).

Women's shyness in getting involved in politics is a reflection of a society that is still looking for its values, balance and the optimal formula for a political class with many credibility issues. At the same time, the attitude of the big parties is clearly patriarchal. Decisions are made by men, women are neglected or forgotten in the process of involvement and some accidents of female representation, especially at the level of central authorities are due to circumstances that are not necessarily related to the political representation of women. As long as in Romania, there was not a mandatory/legislated quota of female representation, nor did the parties by their statute provide for such a thing. The spontaneity of the political class and the arbitrariness continue to dominate a political scene highly marked by a communist heritage, although during the communist period, women's representation was much better, because the communist regime could not afford to compromise on "equality" between citizens.

On the other hand, the involvement of women of their own volition is probably not at the highest levels in Romania either. Therefore, the establishment of a favorable framework for the representation of women would be an impetus in creating an awareness of belonging to a society in which they can have a stronger 
word to say by more assiduous involvement in political life and influencing the course of this life in a positive direction.

\section{Acknowledgements}

The authors would like to thank the anonymous reviewers and Marinela Istrate for the valuable comments, suggestions and careful reading of the manuscript.

\section{Conflicts of Interest}

The authors declare no conflicts of interest regarding the publication of this paper.

\section{References}

Alvarez, R. M., Hall, T. E., \& Trechsel, A. H. (2009). Internet Voting in Comparative Perspective: The Case of Estonia. PS: Political Science \& Politics, 42, 497-505. https://doi.org/10.1017/S1049096509090787

Autoritatea Electorala Permanenta [Permanent Electoral Authority]. ROAEP. http://www.roaep.ro/

Băluță, I. (2012). Femeile în spațiul politic din România postcomunistă: De la „jocul” politic la construcția socială. Annals of the University of Bucharest/Political Science Series, 14, 87-95.

Biroul Electoral Central (BEC) [Central Electoral Office]. https://www.bec.ro

Childs, S., \& Krook, M. L. (2006). Should Feminists Give up on Critical Mass? A Contingent Yes. Politics and Gender, 2, 522-530. https://doi.org/10.1017/S1743923X06251146

Childs, S., \& Krook, M. L. (2008). Critical Mass Theory and Women's Political Representation. Political Studies, 56, 725-736. https://doi.org/10.1111/j.1467-9248.2007.00712.x

CLRAE (Congress of Local and Regional Authorities in Europe) (2004). Explanatory Memorandum on Advantages and Disadvantages of Directly Elected Local Executive in the Light of the Principles of the European Charter of Local Self-Government.

Coffé, H. (2013). Gender and Political Participation in Western and Eastern Europe. In K. Demetriou (Ed.), Democracy in Transition (pp. 95-107). Springer. https://doi.org/10.1007/978-3-642-30068-4 6

Comșa, M. (2015). Turnout Decline in Romanian National Elections: Is It that Big? Studia Universitatis Babes-Bolyai Sociologia, 6, 59-84.

https://doi.org/10.1515/subbs-2015-0010

Council of European Municipalities and Regions (CEMR) (2010). Status of Local Elected Representatives in Europe.

Council of European Municipalities and Regions (CEMR) (2011). Local and Regional Government in Europe. Structures and Competences.

Czyż, A. (2009). Samorząd terytorialny w Republice Węgier. In M. Barański (Ed.), Samorząd terytorialny $w$ państwach Europy Środkowej $i$ Wschodniej. Wydawnictwo Adam Marszałek.

Dumitriu, R., Muntele, I., Marcu, S., \& Dumitriu, A., (2013). Migratiile internationale ale populatiei din Moldova. Editura Universitatii Alexandru Ioan Cuza.

European Institute of Gender Equality. http://eige.europa.eu

Fedor, A. D., Istrate, M., \& Iațu, C. (2021). Equal Opportunities in Romanian Politics- 
Work in Progress. A Chronological and Spatial Analysis of Women's Participation in Political Life. In International Scientific Conference GEOBALCANICA 2021 (pp. 237-244). Skopje: Geobalcanica Society. https://doi.org/10.18509/GBP210237f

Frandsen, A. G. (2002). Size and Electoral Participation in Local Elections. Environment and Planning C: Government and Policy, 20, 853-869. https://doi.org/10.1068/c0228

Galligan, Y., \& Clavero, S. (2005). “A Job in Politics Is Not for Women”: Analysing Barriers to Women's Political Representation in CEE. Sociologický Časopis/Czech Sociological Review, 41, 979-1004. https://nbn-resolving.org/urn:nbn:de:0168-ssoar-54821

Gârboni, E. S. (2014). Women in Politics during the Romanian Transition. ProcediaSocial and Behavioral Sciences, 163, 247-256. https://doi.org/10.1016/j.sbspro.2014.12.313

Górecki, M. A., \& Gendźwiłł, A. (2020). Polity Size and Voter Turnout Revisited: Micro-Level Evidence from 14 Countries of Central and Eastern Europe. Local Government Studies, 47, 31-53. https://doi.org/10.1080/03003930.2020.1787165

Institutul National de Statistica (INS) [National Institute of Statistics]. http://www.insse.ro/

International Institute of Democracy and Electoral Assistance. https://www.idea.int

Kantola, J. (2019). Women's Organizations of Political Parties: Formal Possibilities, Informal Challenges and Discursive Controversies. NORA-Nordic Journal of Feminist and Gender Research, 27, 4-21. https://doi.org/10.1080/08038740.2018.1529703

Kāršenieks, J. (2016). Latvian Administrative Territorial Reform Assessment. In Proceedings of the 58th International Scientific Conference of Daugavpils University (pp. 120-127). Daugavpils Universitāte Akadēmiskais Apgāds, Saule.

https://dukonference.lv/files/proceedings of conf/978-9984-14-779-6 58\%20konf\%20 kraj B Soc\%20zin.pdf

Knott, E. (2017). The Extra-Territorial Paradox of Voting: The Duty to Vote in ExtraTerritorial Elections. Democratization, 24, 325-346. https://doi.org/10.1080/13510347.2016.1189904

Köppl-Turyna, M., \& Kantorowicz, J. (2020). The Effect of Quotas on Female Representation in Local Politics. Research Paper No. 15, EcoAustria-Institute for Economic Research.

Kostadinova, T. (2003). Voter Turnout Dynamics in Post-Communist Europe. European Journal of Political Research, 42, 741-759. https://doi.org/10.1111/1475-6765.00102

Ladner, A., Keuffer, N., Baldersheim, H., Hlepas, N., Swianiewicz, P., Steyvers, K., \& Navarro, C. (2019). Patterns of Local Autonomy in Europe. Palgrave Macmillan. https://doi.org/10.1007/978-3-319-95642-8

Legea nr. 115/2015 pentru alegerea autoritatilor administratiei locale [Law Number 115 from 2015 for Local Administration Authority Election].

Legea nr. 215/2001 a administratiei publice locale [Law Number 215 from 2001 of Local Public Administration].

Massino, J., \& Popa, R. M. (2015). The Good, the Bad, and the Ambiguous: Women and the Transition from Communism to Pluralism in Romania. In C. M. Hassenstab, \& S. P. Ramet (Eds.), Gender (In)equality and Gender Politics in Southeastern Europe (pp. 171-191). Palgrave Macmillan. https://doi.org/10.1057/9781137449924 9

Matei, E., Iațu, C., \& Vert, C. (2010). Romanian Woman Involvement in Governance after 1990. Geographica Pannonica, 14, 1-13. https://doi.org/10.5937/GeoPan1001001M

McGregor, J., \& Webster, K. (2017). Women’s Local Government Representation in 
Auckland-Does Size Matter? Commonwealth Journal of Local Governance, 20, 1-20.

Millard, F. (2014). Not Much Happened: The Impact of Gender Quotas in Poland. Communist and Post-Communist Studies, 47, 1-11. https://doi.org/10.1016/j.postcomstud.2014.01.004

Mishler, W., \& Rose, R. (1997). Trust, Distrust and Skepticism: Popular Evaluations of Civil and Political Institutions in Post-Communist Societies. The Journal of Politics, 59, 418-451. https://doi.org/10.1017/S0022381600053512

Montgomery, A. K., \& Ilonski, G. (2016). Stuck in the Basement: A Pathway Case Analysis of Female Recruitment in Hungary's 2010 National Assembly Elections. Politics and Gender, 12, 700-726.

Ordonanță de urgență nr. 57/2019 [Emergency Decree Number 57 from 2019 Related to the Administrative Code].

Podolnjak, R., \& Gardašević, D. (2013). Directly Elected Mayors and the Problem of Cohabitation: The Case of the Croatian Capital Zagreb. Elections and Democracy, 20, 79-96.

Rajca, L. (2021). The Position of Mayor Within Local Authority Relations in Hungary and Poland in a Comparative. Środkowoeuropejskie Studia Polityczne, No. 1, 71-88. https://doi.org/10.14746/ssp.2021.1.5

Răuțu, I. S. (2020). Strategii de mobilizare electorală folosite de partidele politice din România la alegerile locale din 27 septembrie 2020. Studiu de caz: Județul Botoșani. Revista Română de Studii Electorale, 8.

Selisnik, I., \& Gaber, M. (2015). From Voluntary Party to Legal Electoral Gender Quotas in Slovenia: The Importance and Limitations of Legal and Institutional Mechanisms. European University Institute. https://doi.org/10.2139/ssrn.2610662

Sloat, A. (2004). Fixing an Old Divide: The Political Participation of Women in an Enlarged Europe, Research Project Entitled "Enlargement, Gender and Governance: The Civic and Political Participation and Representation of Women in EU Candidate Countries" (EGG).

Statutul Partidului National Liberal [PNL Party Statue]. https://pnl.ro/documente-fundamentale/statut/

Statutul Partidului Social Democrat [PSD Party Statue]. https://www.psd.ro/structura-si-organizatii/statut/

Statutul Partidului UDMR [UDMR Party Statue]. http://udmr.ro/upload/dokumetumok/Statut UDMR 2017.pdf

Statutul Partidului USRPLUS [USRPLUS Party Statue]. https://www.usr.ro/statut/

Sundstrom, A., \& Wängnerud, L. (2016). Corruption as an Obstacle to Women's Political Representation: Evidence from Local Councils in 18 European Countries. Party Politics, 22, 354-369. https://doi.org/10.1177/1354068814549339

Sung, Y. (2011). Elections in a Multi-Party Political System. Theoretical Economics Letters, 1, 18-20. https://doi.org/10.4236/tel.2011.12005

Swai, I., \& Anasel, M. (2020). What Are They Speaking for: The Relative Participation of Female Councillors on Influencing "Health Related Female Interests" in the Decision Making Processes. Advances in Applied Sociology, 10, 11-22. https://doi.org/10.4236/aasoci.2020.102002

Timár, J. (2004). Gendered Urban Policy-Making; the Role of Geographical Scale in Women's Participation in Hungarian Local Governments, Gendered Cities. Identities, Activities, Networks. In G. Cortesi, F. Cristaldi, \& F. Droogleever (Eds.), A Life-Course Approach (pp. 227-243). Societa Geografica Italiana. 
Timár, J. (2005). Gender and Spatial Inequalities in Hungary in the Transition Era. In G. Barta, É. G. Fekete, I. Kukorelli Szörényiné, \& J. Timár (Eds.), Hungarian Spaces and Places: Patterns of Transition (pp. 307-322). Pécs, Centre for Regional Studies.

Várnagy, R., \& Ilonski, G. (2012). Üvegplafonok. Pártok Lent És Fent. Politikatudományi Szemle, 21, 7-25. 